\title{
Ewolucja sejmów walnych okresu regnum w latach 1587-1668
} $S$ taropolski parlamentaryzm to jedno z najciekawszych zagadnień cyfika sejmów walnych była związana z terminem ich odbywania, a mianowicie tym, czy były zwołane w czasie panowania monarchy (regnum), czy w okresie bezkrólewia (interregnum), wreszcie, w tych przedziałach czasowych także znane były ich różne rodzaje. Niniejszy artykuł dotyczy klasyfikacji sejmów, zwoływanych przez panujących monarchów z dynastii Wazów: Zygmunta III, Władysława IV oraz Jana Kazimierza.

\section{Sejmy zwyczajne i nadzwyczajne za panowania Zygmunta III Wazy (1587-1632)}

Wokół problematyki postanowienia Artykułów henrykowskich o zwoływaniu sejmu narosło, jak może wokół żadnej innej sprawy, bardzo dużo kontrowersji ${ }^{1}$. Ów, budzący tyle wątpliwości przepis, brzmi następująco: „Sejm walny koronny we dwie lecie nadalej ma być składan, a gdzieby tego była pilna a gwałtowna potrzeba Rzeczypospolitej, tedy za radą panow rad obojga państwa, iako czas i potrzeba Rzeczypospolitej przynosić będzie, powinni go składać będziemy. A dłużej go dzierżeć nie mamy, nadalej do sześci niedziel" ${ }^{2}$.

W literaturze przedmiotu dominowała jeszcze do niedawna interpretacja tego przepisu, zgodna $\mathrm{z}$ ustaleniami sprzed ponad stu lat, a mianowi-

${ }^{1} 1573$, pkt [9], VC, t. II. 1550-1609, v. 1. 1550-1585, do druku przygotowali S. Grodziski, I. Dwornicka i W. Uruszczak, Warszawa 2005, s. 328; 1576, pkt 7, tamże, s. 357; 1576, pkt 8; VL, t. II, 1550-1609, wyd. J. Ohryzko, Petersburg 1859, s. 161.

${ }^{2}$ VC, t. II, 1, s. 357. 
cie, że sejmy, w świetle Artykułów henrykowskich dzieliły się na zwyczajne (ordynaryjne), trwające sześć tygodni oraz nadzwyczajne (ekstraordynaryjne), trwające dwa-trzy tygodnie ${ }^{3}$. Przekonanie o występującym w tym akcie podziale wywodziło się, być może, z dzieła Godfryda Lengnicha, w którym znajdował się passus następującej treści: „Sejmy dzielą się na zwyczajne i nadzwyczajne; ów zaś podział od roku 1573 nastał, w którym wydana była ustawa, sejm co dwa lata nakazująca, a dozwalająca zarazem królowi, i w krótszym przeciągu czasu takowy zwołać, gdyby tego dobro publiczne wymagało. Od tego bowiem czasu sejmy co dwa lata odbywane, zwyczajnymi (ordynaryjnymi) zwać poczęto, inne zaś, dla różnicy, nadzwyczajnymi (ekstraordynaryjnymi)"4. Moim zdaniem, co próbowałam dowieść w jednej ze swych wcześniejszych publikacji, Lengnich wprowadził czytelników w błąd, przenosząc doświadczenia XVIII-wieczne na czasy wcześniejsze 5 .

Nie wszyscy jednak skwapliwie podchwycili tę tezę. Piszący w podobnym, co Lengnich, okresie - Wincenty Skrzetuski nie forsował w sposób zdecydowany tego twierdzenia. Pisał, że sejmy zwoływane były co dwa lata. Tego rodzaju sejmy nazwał sejmami zwyczajnymi, wspominając, że bywały także składane częściej, „w przypadku nagłej na Rzeczpospolitą potrzeby". Używał też określenia sejmy ekstraordynaryjne, jednak zaznaczając, że poprzedzały je rady senatu ${ }^{6}$.

Niejasność przepisów dała niektórym badaczom asumpt do wyrażania wątpliwości odnośnie do stosowanego podziału. Stanisław Płaza i Anna Sucheni-Grabowska uznawali występowanie w Artykułach henrykowskich obu rodzajów sejmów (zwyczajnych i nadzwyczajnych), jednak zaznaczali, że $w$ świetle treści tego dokumentu nie były znane sejmy dwu- lub trzytygodniowe. Ich zdaniem, powstały one de facto, a nie de iure, wiążąc pierwszy sejm nadzwyczajny krótki z rokiem $1613^{7}$. Co prawda S. Płaza twierdził w późniejszym czasie, że sformułowany w artykułach termin ad quem dopuszczał istnienie sejmów krótszych, co skłoniło go do głoszenia poglądu, że w Artykułach przewidziano możliwość zwoływania, za radą senatu, również dwutygodniowych sejmów nadzwyczajnych ${ }^{8}$.

${ }^{3}$ S. Kutrzeba, Historia ustroju Polski w zarysie, Lwów 1908, s. 180-181, podobnie E. Opaliński, Sejm srebrnego wieku 1587-1652, Warszawa 2001, s. 15.

${ }^{4}$ G. Lengnich, Prawo pospolite Królestwa Polskiego, Kraków 1836, s. 342.

${ }^{5}$ I. Lewandowska-Malec, Sejmy nadzwyczajne w dziejach polskiego parlamentaryzmu, „Studia z Dziejów Państwa i Prawa Polskiego" [Kraków] 2007, t. X.

${ }^{6}$ W. Skrzetuski, Prawo pospolite narodu polskiego, t. I, Warszawa 1782, s. 250, 253.

${ }^{7}$ S. Płaza, A. Sucheni-Grabowska, Z badań nad parlamentaryzmem XVI wieku, CPH, 1974, t. XXVI, z. 1, s. 72.

${ }^{8}$ S. Płaza, Wielkie bezkrólewia, Kraków 1988, s. 76 [ser. Dzieje_Narodu i Państwa Polskiego, II-22]. 
Problemy z interpretacją tego postanowienia Artykułów sprowokowały kilku autorów do formułowania własnej wykładni. Do autorów tych należał m.in. Janusz Dorobisz, który w swoich publikacjach uznał, że przewidywane, jego zdaniem, sejmy nadzwyczajne w Artykułach henrykowskich miały bliżej nieokreśloną procedurę i czas trwania9. Regulacja ta została skonkretyzowana przepisami szczególnymi na sejmie krakowskim w 1595 r. ${ }^{10}$ Koncepcja autora budzi jednak istotne zastrzeżenia. Norma szczególna nie może stać bowiem w sprzeczności z normą ogólna, skoro ma ją konkretyzować. Powinna nawet się na nią powoływać dla określenia celu, dla jakiego powstała. Za taką należy uznać konstytucję sejmu 1591 r., określającą precyzyjnie czas trwania sejmu na sześć tygodni oraz sposób liczenia tego terminu. Ówczesny ustawodawca powołał się zresztą na Artykuły henrykowskie, stwierdzając, że: „Iż to do wątpliwości przychodzi u ludzi, iako się sejm kończyć ma, tedy konstytucye o tym uczynione tak deklarujemy [...]"11. Odnośnie jednak do normy szczególnej, o której J. Dorobisz pisze w kontekście konstytucji sejmu 1595 r., ta nie konkretyzuje normy ogólnej, lecz wyłącza jej zastosowanie („,lex specialis derogat legi generali"). Niemniej jednak badacz ów zauważył, że zwołany w 1613 r. sejm, który trwał trzy tygodnie, odbiegał od formuły narzuconej uchwałą sejmu 1595 r., gdyż rozesłano deliberatoria, których konstytucja ta nie przewidywała. Za pierwszy sejm stricte nadzwyczajny dwutygodniowy uznał sejm w $1624 \mathrm{r}^{12}$

Analizując bliżej relacje między sejmami zwyczajnymi a nadzwyczajnymi epoki Zygmunta III (schemat 1) można dojść do wniosku, że Artykuły henrykowskie w ogóle nie przewidywały sejmów ekstraordynaryjnych. Ich powstanie zostało wymuszone trudną sytuacją państwa w 1613 r., a zwołując to zgromadzenie Zygmunt III skorzystał z doświadczeń sejmu krakowskiego 1595 r., przede wszystkim mając na celu skrócenie obrad sejmowych ${ }^{13}$.

${ }^{9}$ J. Dorobisz, Sejm nadzwyczajny z 1624 roku, Opole 1994; tenże, Z problematyki procedury sejmów nadzwyczajnych za Zygmunta III, [w:] Studia z Dziejów Rzeczypospolitej Szlacheckiej, AUWr, 945, Historia, t. LXVI, Wrocław 1988.

${ }^{10}$ J. Dorobisz, Z problematyki..., s. 133, por. 1595; VL, t. II, s. 355.

${ }^{11} 1591$, pkt. 15, O sejmie, VC, t. II, 2, s. 178.

${ }^{12}$ J. Dorobisz, Sejm nadzwyczajny..., s. 95.

${ }^{13} \mathrm{~W}$ tej sprawie obszerna analiza w I. Lewandowska-Malec, Sejm walny koronny Rzeczypospolitej Obojga Narodów i jego dorobek ustawodawczy (1587-1632), Kraków 2009, s. 37-53. 


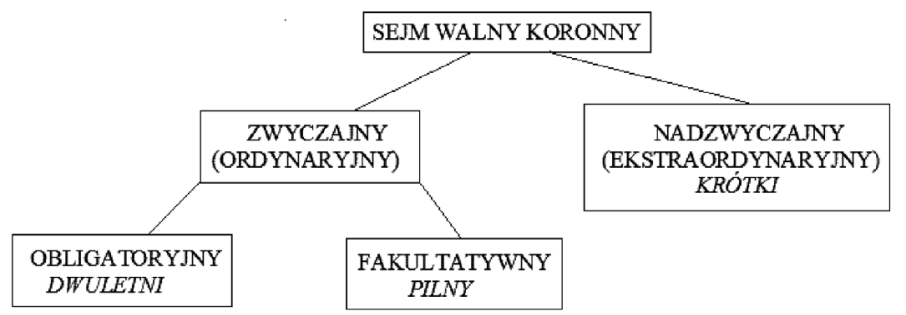

Schemat 1. Sejmy zwyczajne i nadzwyczajne za Zygmunta III Wazy Źródło: opracowanie własne.

\section{Sejmy zwyczajne i nadzwyczajne za panowania Władysława IV Wazy (1633-1648)}

Rozważaniom w tej sprawie poświęcił wiele miejsca Przemysław Paradowski, autor książki W obliczu "nagłych potrzeb" Rzeczypospolitej. Sejmy ekstraordynaryjne za panowania Władysława IV Wazy. Badacz przychylił się do zdania J. Dorobisza, że Artykuły henrykowskie uszczegółowiono konstytucją sejmu 1595 r. Sformułował koncepcję sejmów nadzwyczajnych, dzielących się na dwa rodzaje, a mianowicie ekstraordynaryjne sejmy dodatkowe wynikające z Artykułów henrykowskich oraz skrócone sejmy ekstraordynaryjne, zwoływane każdorazowo uchwałą poprzedniego sejmu zwyczajnego ${ }^{14}$.

Szlachta postanowiła ostatecznie zerwać z sejmami nadzwyczajnymi w roku 1637. Wcześniej, już za panowania Władysława IV, zwołano je w 1634 i 1635 r. mocą szczególnych konstytucji poprzednich sejmów zwyczajnych ${ }^{15}$. W roku 1637 doszło do niezwyczajnej sytuacji. Sejm, rozpoczęty 20 stycznia 1637 r., rozszedł się bez dorobku ustawodawczego 4 marca o świcie ${ }^{16}$. Tymczasem, w trzy miesiące później, król zwołał kolejny sejm jako nadzwyczajny. Władca próbował za podstawę prawną przyjąć uchwałę rady senatu (z 4 i 6 marca), nawiązując tym samym do przepisów Artykułów henrykowskich o możliwości zwołania sejmu za radą senatoró $w^{17}$. Pominął jednak fakt, że postanowienia te nie przewidywały skrócenia obrad. Ta nadinterpretacja nie uszła królowi płazem. Już

${ }^{14}$ P. Paradowski, W obliczu "nagłych potrzeb" Rzeczypospolitej. Sejmy ekstraordynaryjne za panowania Władysława IV Wazy, Torun 2005, s. 22-28.

${ }^{15}$ 1633, pkt 8, Seym dwuniedzielny, VL, t. III, s. 373, 1635, pkt 36, Seym dwuniedzielny, tamże, s. 413, por. P. Paradowski, W obliczu..., s. 216-222.

${ }^{16}$ R. Kołodziej, Pierwszy sejm z 1637 roku, Toruń 2004, s. 103, 122, 244.

${ }^{17}$ P. Paradowski, W obliczu..., s. 39. 
niektóre sejmiki przedsejmowe zareagowały protestacyjnie. W Środzie postanowiono nie wysyłać posłów na sejm: „,[...] iednak, iż Woiewództwa Wielgopolskie Posłów swych nań dla tego nie posłali, że Seymem sześć niedzielnym nie był naznaczony"18. W trakcie obrad podano w wątpliwość legalność jego zwołania ${ }^{19}$. W efekcie podjęto na tym sejmie uchwałę, w której król zobowiązywał się, że ani on, ani jego następcy nie będą zwoływać sejmów dwuniedzielnych. Pozwolono jednocześnie na ograniczoną nowelizację Artykułów henrykowskich, przewidując możliwość skrócenia solennitates, gdy planowano sejm zwyczajny fakultatywny. Sejm ten jednak, jak dotychczas, mógł zostać zwołany jedynie po uzyskaniu rady senatorów.

Sytuacja w roku 1637 zdawała się klarowna. Sejmy zwyczajne planowano odbywać co dwa lata, a jeśli konieczność tego wymagała, w okresie pomiędzy sejmami obligatoryjnymi król mógł zwołać, po wcześniejszym zasięgnięciu opinii senatorów, sejm zwyczajny fakultatywny, przyśpieszony dzięki rezygnacji z różnych ceremonialnych czynności przedsejmowych ${ }^{20}$. Sejmy te, niezależnie od okoliczności zwołania, miały trwać zawsze sześć tygodni ${ }^{21}$. Zdawało się, że tak krytykowane sejmy nadzwyczajne odeszły w niepamięć, zwłaszcza że konstytucję tę potwierdzono na następnym sejmie, z tą zmiana, że sejmiki przed sejmami zwyczajnymi fakultatywnymi miały się odbywać na cztery tygodnie przed sejmem ${ }^{22}$. Jednocześnie na tym samym sejmie uchwalono konstytucję upoważniającą króla do zwołania sejmu nadzwyczajnego, jeśli zaistnieją okoliczności opisane $\mathrm{w}$ przyjętym skrypcie do archiwum ${ }^{23}$. W arendze wyjaśniono powody takiej decyzji; uznano za rzecz niedopuszczalną zwołanie przez króla sejmu ekstraordynaryjnego bez uprzedniej uchwały sejmu zwyczajnego. Przyjęto, że tylko takie sejmy nadzwyczajne są sprzeczne z prawem. Chaos, jaki wkradł się do trybu sejmowania, był tu aż nadto widoczny. $Z$ jednej strony zezwolono na zwoływanie jedynie sejmów sześciotygodniowych, z drugiej dopuszczano jego złożenie jako nadzwyczajnego za specjalnym sejmowym upoważnieniem. Obie uchwały, za-

${ }^{18} 1638, V L$, t. III, s. 438.

${ }^{19}$ P. Paradowski, W obliczu..., s. 92-93.

${ }^{20}$ „przychylając się do sentencyi Panów Senatorów Obojga Narodów, którą Nam praesentea w Warszawie na przeszłym sejmie otworzyli, gdzieby tempestas wojny pogańskiej zastępowała, abyśmy absque omnibus solennitatibus z skróceniem czasów zwyczajnych, które prawo mieć chce w składaniu ordynaryjnem sejmów walnych, sejm sześćniedzielny podług konstytucyi anni 1637 złożyli", uniwersał Władysława IV, zwołujący sejm i sejmiki, Warszawa, luty 1640, A. Podgórski, Pomniki dziejów..., s. 17.

${ }^{21}$ „byle przecięż Seym Walny sześć niedzielny był złożony”, VL, t. III, s. 433.

${ }^{22} 1638$, VL, t. III, s. 438.

${ }^{23}$ Pkt 6, Seym dwuniedzielny, VL, t. III, s. 439. 
padłe na tym samym sejmie, nawzajem się wykluczały. Jednak wówczas, po raz pierwszy $w$ historii, monarcha nie zwołał sejmu nadzwyczajnego, pomimo upoważnienia od sejmu zwyczajnego. Być może powodem były zarzuty, że konstytucja upoważniająca monarchę do zwołania sejmu dwuniedzielnego nie została uchwalona na konkluzji za zgodą wszystkich posłów i została dopisana do pakietu uchwalonych uchwał już na etapie ich ucierania - sejm 1639 r. został zwołany jako zwyczajny ${ }^{24}$.

Przyszłość pokazała jednak, że sejmy ekstraordynaryjne są konieczne, pomimo że zabronione prawem. Na sejmie w roku 1641 pojawiła się nowa forma ich inicjowania. W celu obejścia zakazu ich zwoływania postanowiono, że nie król, lecz sam sejm będzie jedynym uprawnionym podmiotem ich składania. Uchwalono wówczas po raz pierwszy konstytucję wyznaczającą datę dzienną rozpoczęcia sejmu (11 lutego 1642) oraz daty zwołania sejmików przedsejmowych na 7 stycznia, ponad to określono dokładnie program obrad tego sejmu ${ }^{25}$. $\mathrm{Z}$ formalnego punktu widzenia uchwała ta nie była jednoznacznie sprzeczna $z$ dotychczasowym prawem o sejmach, skoro nie przekazywano królowi uprawnienia do zwołania sejmu „krótkiego”, lecz kreowano jego nowy rodzaj, mocą suwerennej decyzji sejmu poprzedniego. Była to jednak kolejna próba obejścia prawa pospolitego o szczególnym znaczeniu, trwałego i niezmiennego. Wzbudziła zatem protesty szlachty przed i w trakcie sejmu roku $1642^{26}$.

Na sejmie w roku 1646 podjęto uchwałę taką jak w roku 1641; postanowiono bowiem, mocą uchwały sejmowej, zwołać sejm nadzwyczajny na 2 maja 1647 r., sejmiki zaś przedsejmowe wyznaczono na 11 kwietnia ${ }^{27}$. Sejm ten był rzeczywiście niezwykły, gdyż debatowano na nim głównie nad egzorbitancjami i postulatami województw i ziem, co było sprzeczne $\mathrm{z}$ materią dotychczas dyskutowaną na sejmach ekstraordynaryjnych (obrona i podatki) ${ }^{28}$.

W efekcie za Władysława IV, miała nastąpić radykalna zmiana w podejściu do sejmów nadzwyczajnych. W początkach jego panowania dążono do ich likwidacji, natomiast pod koniec stworzono dla nich nową formułę 29 .

W odniesieniu do klasyfikacji sejmów nie nastąpiła jednak żadna metamorfoza; nadal aktualny był podział przedstawiony na schemacie 1 .

\footnotetext{
${ }^{24}$ W. Konopczyński, Chronologia sejmów polskich 1493-1793, Kraków 1948, s. 151.

${ }^{25}$ 1641, pkt 14, Seym dwuniedzielny, VL, t. IV, s. 9-10.

${ }^{26}$ P. Paradowski, W obliczu..., s. 93.

${ }^{27} 1646$, pkt 8, Seym extraordynaryjny, VL, t. IV, s. 46.

${ }^{28} 1647, V L$, t. IV, s. 51-52.

${ }^{29}$ Por. P. Paradowski, W obliczu..., s. 40.
} 


\section{Sejmy zwyczajne i nadzwyczajne za panowania Jana Kazimierza Wazy (1649-1668)}

Problematykę rodzajów sejmów podjęli również S. Ochmann-Staniszewska i Z. Staniszewski w dwutomowym dziele Sejm Rzeczypospolitej za panowania Jana Kazimierza Wazy. Prawo - doktryna - praktyka. Autorzy wyszli z założenia, że w Artykułach henrykowskich określono termin zwołania i czas trwania sejmów zwyczajnych i nadzwyczajnych ${ }^{30} . Z$ jednej strony stwierdzili, że w 1591 r. określono czas trwania "każdego" sejmu, z drugiej jednak strony przyjęli, że Artykuły nie wspominały o „kadencji skróconej"31. Badacze uznali zatem, że normy prawnej dotyczącej sejmów krótkich nie było, a zatem Wazowie zwoływali sejmy skrócone mocą faktów, nie zaś prawa ${ }^{32}$. Zauważono przy tym, że w roku 1637 uchwalono konstytucję zakazującą zwoływania sejmów nadzwyczajnych dwu- lub trzytygodniowych. To dało autorom asumpt do twierdzenia, że jeśli król chciał odbyć sejm krótki, to zgodę na to musiał wyrazić sejm poprzedni lub dany sejm zwołany jako sześciotygodniowy ${ }^{33}$. Tym sposobem badacze wyróżnili sejmy zwyczajne sześciotygodniowe i wachlarz sejmów nadzwyczajnych, a to: nadzwyczajne sześciotygodniowe, nadzwyczajne dwutygodniowe, nadzwyczajne sześciotygodniowe skrócone do dwu lub trzech tygodni, a także nadzwyczajne dwutygodniowe przedłużone do sześciu tygodni ${ }^{34}$. Koncepcję autorów zobrazowałam na schemacie 2.

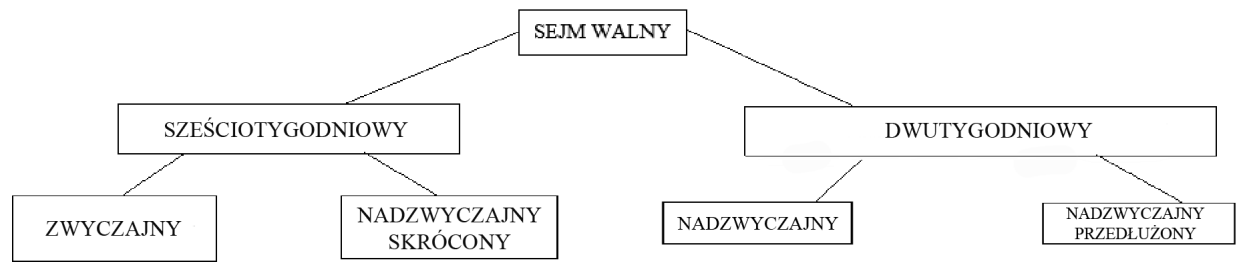

Schemat 2. Rodzaje sejmów za Jana Kazimierza Wazy

Źródło: opracowanie własne na podstawie S. Ochmann-Staniszewska, Z. Staniszewski, Sejm Rzeczypospolitej za panowania Jana Kazimierza Wazy: Prawo - doktryna - praktyka, t. II, Wrocław 2000, s. 7.

${ }^{30}$ S. Ochmann-Staniszewska, Z. Staniszewski, Sejm Rzeczypospolitej za panowania Jana Kazimierza Wazy. Prawo - doktryna - praktyka, t. II, AUWr, 2258, Historia, t. CXLVII, Wrocław 2000, s. 6.

${ }^{31}$ Tamże, por. przyp. 1.

32 Tamże.

${ }_{33}$ Tamże, s. 7.

${ }^{34}$ Tamże, por. tab. 1, s. 7. 
Do tej koncepcji nasuwają się poniższe uwagi:

I. Sejmy dwu-trzytygodniowe: sejm koronacyjny w $1649 \mathrm{r}$. jako nadzwyczajny trzytygodniowy zwołany uchwałą sejmu elekcyjnego ${ }^{35}$. Sejm w 1650 r. zwołany uchwałą sejmu poprzedniego ${ }^{36}$. Sejm 1653 r. zwołany uchwałą sejmu poprzedniego ${ }^{37}$. Sejm w $1655 \mathrm{r}$. zwołany przy braku uchwały sejmu poprzedniego - na mocy uchwały Rady Senatu. Nie było to oczywiste uprawnienie senatorów, gdyż król w instrukcji na sejmiki prosił o wyrażenie zgody na obrady dwutygodniowe ${ }^{38}$. Gdyby uprawnienie Rady Senatu wynikało z Artykułów henrykowskich monarcha nie musiałby o to prosić. Analogiczna sytuacja w przypadku sejmu $1665 \mathrm{r}$. (dodatkowo sejmu nadzwyczajnego domagali się Litwini na sesji posejmowej 8-10 stycznia). $\mathrm{W}$ tym wypadku sejm zaplanowano po poprzednim zerwanym sejmie. Szlachta na sejmikach twierdziła, że sejm ten jest nielegalny ${ }^{39}$.

Były to sejmy zwołane głównie mocą uchwały sejmu poprzedniego lub, jak sejm z 1613 r., bez podstawy prawnej, jednak izba poselska, pomimo zastrzeżeń i zarzutów nielegalności, ostatecznie przychyliła się do odbycia ich w tym trybie. Należy je zatem uznać za sejmy nadzwyczajne z powodu krótkiego czasu obrad oraz szczególnej podstawy prawnej ich zwołania.

II. Sejmy sześciotygodniowe skrócone do dwu-trzech tygodni: Drugi sejm w 1652 r. po poprzednim sejmie zerwanym. Zwołany jako zwyczajny, po propozycji od tronu podkanclerzy zgłosił pomysł skrócenia obrad do dwu tygodni. Posłowie wyrazili zgodę. Sejm uchwalił konstytucję o skróceniu obrad ${ }^{40}$. Także drugi sejm w $1654 \mathrm{r}$. po poprzednim zerwanym zwołany jako sześciotygodniowy, ale już w instrukcji znalazła się propozycja jego skrócenia do dwu tygodni. Ostatecznie izba poselska zgodziła się na skrócenie go do trzech tygodni, powziąwszy stosowną uchwałe, przyjętą następnie na konkluzji ${ }^{41}$. Także drugi sejm $\mathrm{w} 1668 \mathrm{r}$. z powodu zagrożenia tureckiego zwołany jednak jako sześciotygodniowy. W instrukcji znajdowała się sugestia, że właściwszy w tej sytuacji byłby sejm dwutygodniowy. Całkowicie nietypowy - przebiegał pod znakiem zamiaru abdykacji przez króla ${ }^{42}$.

\footnotetext{
${ }^{35}$ S. Ochmann-Staniszewska, Z. Staniszewski, Sejm Rzeczypospolitej..., t. I, s. 23-24.

${ }^{36}$ Tamże, s. 66.

${ }^{37}$ Tamże, s. 143.

38 Tamże, s. 231.

${ }^{39}$ Tamże, s. 376, 385.

${ }^{40}$ Tamże, s. 136, por. 1652, pkt 2, Skrócenie Seymu, VL, t. IV, s. 165.

${ }^{41}$ S. Ochmann-Staniszewska, Z. Staniszewski, Sejm Rzeczypospolitej..., s. 211; VL, t. IV,

${ }^{42}$ Tamże, s. 573-574.
} s. 443. 
Powyższe sejmy miały niewątpliwie charakter nadzwyczajnych. Zastosowano nową metodę legitymizowania sejmów nadzwyczajnych już nie uchwała sejmu poprzedniego, lecz danego sejmu.

III. Sejm nadzwyczajny dwutygodniowy przedłużony do sześciu tygodni, zwołany przez króla w 1667 r. po sejmie zerwanym, a więc bez upoważnienia. Zdawał sobie $\mathrm{z}$ tego sprawę król, dopuszczał więc $\mathrm{w}$ instrukcji obrady sześciotygodniowe. Tak też się stało ${ }^{43}$.

Był to, moim zdaniem, sejm zwyczajny. Nie było podstaw prawnych do uznania tego sejmu za nadzwyczajny; nie istniała uchwała sejmu poprzedniego o zwołaniu sejmu "krótkiego", na danym sejmie szlachta również nie podjęła uchwały o skróceniu jego obrad. Sejm więc odbywał się w trybie zwyczajnym jako sześciotygodniowy.

IV. Sejm nadzwyczajny sześciotygodniowy: w 1659 r. zwołany sejm autorzy kwalifikują jako nadzwyczajny, choć uchwała o zwołaniu takiego sejmu nie znalazła się wśród przedrukowanych powtórnie konstytucji tego sejmu ${ }^{44}$.

Moim zdaniem to sejm zwyczajny, wywołany nagłymi potrzebami państwa. Żaden mianowicie sejm zwołany na podstawie Artykułów henrykowskich nie może zostać uznany za nadzwyczajny, gdyż nazwa ta w literaturze historycznej i historyczno-prawnej jest ściśle związana z sejmami dwu-trzytygodniowymi. Jeśli więc pozostawia się dla tychże sejmów nazwę „nadzwyczajne”, to nie można jej w żadnym wypadku łączyć z sejmami zwoływanymi w trybie Artykułów henrykowskich. Ponadto brak jest argumentów dla uznania nadzwyczajności sejmów zwoływanych wcześniej niż co dwa lata, skoro odbywały się wedle tej samej procedury co sejmy ordynaryjne (zwyczajne - „dwuletnie”). Przy przyjęciu tezy przeciwnej natychmiast ujawniłyby się problemy z kwalifikowaniem owych sejmów, a zatem, czy sejm zwołany po upływie półtora roku jest zwyczajny czy nadzwyczajny. Jeśliby uznać sejmy zwołane wcześniej niż w okresie dwulecia za nadzwyczajne, to ich liczba przeważałaby nad sejmami zwyczajnymi, a sejmy z okresu 1588-1613 w znaczącej części utraciłyby dotychczasową kwalifikację. Przykładowo, skoro po sejmie koronacyjnym Zygmunta III (1587-1588) kolejny zwołano w 1589 r.; w świetle rozważań S. Ochmann-Staniszewskiej, Z. Staniszewskiego czy P. Paradowskiego powinien zostać uznany za nadzwyczajny, zwłaszcza że do jego zwołania zobowiązano króla konstytucją poprzedniego sejmu ${ }^{45}$. Większego sensu nie miałaby również Chronologia sejmów polskich Władysława Konopczyńskiego.

${ }^{43}$ Tamże, s. 492-494.

${ }^{44}$ Tamże, s. 276.

45 1588, pkt VI. Reces sejmu koronacyi, VC, t. II, 1550-1609, v. 2. 1587-1609, do druku przyg. S. Grodziski, przedm. W. Uruszczak, Kraków 2008, s. 87. 
Wydawało się, że sytuacja ulegnie pewnej stabilizacji, jednak w czasach Jana Kazimierza zwoływano sejmy nadzwyczajne zarówno z upoważnienia danego królowi przez sejm poprzedni, jak również mocą konstytucji, wyznaczającej czas, miejsce i tematykę obrad. O sejm nadzwyczajny "in casu necessitas" prosiły też sejmiki ziemskie ${ }^{46}$. Jednak w czasach tego dwudziestolecia sytuacja bardzo się skomplikowała. Siedmiokrotnie sejm rozchodził się bez dorobku ustawodawczego, a więc nie miał możliwości podjęcia uchwały o zwołaniu sejmu nadzwyczajnego. W tej sytuacji król zwoływał zwykle sejm sześciotygodniowy, gdyż próby złożenia sejmu nadzwyczajnego bez tytułu prawnego kończyły się gwałtownymi protestami i zarzutami bezprawia. Ostatecznie wypracowano nową formułę uchwalania konstytucji na obradującym sejmie, na którym zgodnie zezwalano na jego skrócenie, wpisując stosowną uchwałę do pakietu konstytucji. Przejawia się w tej taktyce ponownie zastosowanie zasady lex specialis derogat legi generali. Należy rozważyć, czy sejmy, zwołane jako „sześćniedzielne”, skrócone uchwałą tego sejmu, miały charakter zwyczajny, czy nadzwyczajny. Za pierwszym wnioskiem przemawiałoby określenie sejmu $1668 \mathrm{r}$. jako „sześćniedzielnego ordynaryinego ex consensu totius reipublicae do trzech niedziel skróconego" ${ }^{\prime 7}$. Jednak w arendze wspomniano, że program obrad został ograniczony jedynie do "materiis abdicationis". Podobnie, sejm zwołany w roku 1652 jako sześciotygodniowy skrócono do dwu tygodni z zastrzeżeniem, że w przyszłości praktyka taka nie ma mieć zastosowania: „takowe iednak skrócenie prawu pospolitemu o Seymach, nic in posterum derogować nie ma"48. A zatem traktowano taką sytuację jako wyjątkowa; trudno więc uznać tego rodzaju sejm za zwyczajny (ordynaryjny). Tego rodzaju sejmy należy zakwalifikować jako nadzwyczajne skrócone. Nadal natomiast nie przemawiała do szlachty koncepcja zwołania kolejnego sejmu uchwałą rady senatu. Zwołany na tej podstawie sejm w 1665 r. był niezwykle burzliwy i rozszedł się bez podjęcia uchwał ${ }^{49}$.

W ten sposób w II połowie wieku XVII ukształtowało się szerokie spectrum sejmów walnych, co zobrazowano na schemacie 3.

${ }^{46}$ Przykładowo sejmik sandomierski przed sejmem 1652-I (instrukcja pkt 23), S. Oświęcim, Diariusz 1643-1651, SRP XIX, wyd. W. Czermak, Kraków 1907, Oświęcim, s. 384.

${ }^{47} \mathrm{VL}, \mathrm{t} . \mathrm{IV}, \mathrm{s.} 478$.

48 1652, pkt 2, Skrócenie Seymu, VL, t. IV, s. 165, por. tamże, s. 204 w odniesieniu do sejmu $1654 \mathrm{r}$.

${ }^{49}$ S. Ochmann-Staniszewska, Z. Staniszewski, Sejm Rzeczypospolitej..., t. I, s. 378. 


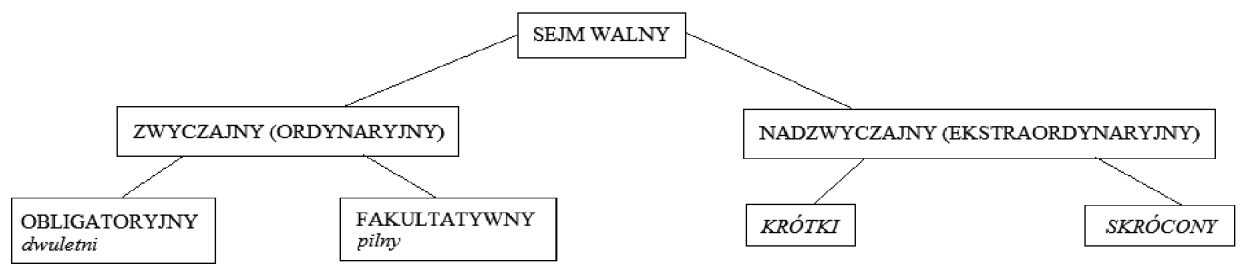

Schemat 3. Sejmy zwyczajne i nadzwyczajne za Jana Kazimierza Wazy Źródło: opracowanie własne.

\section{Podsumowanie}

W czasach Wazów sejmy, zwoływane w czasie panowania monarchy, przeszły istotną ewolucję. Za Zygmunta III pojawiły się, nieznane z Artykułów henrykowskich, sejmy nadzwyczajne (ekstraordynaryjne). Pomimo podjętych za panowania Władysława IV prób likwidacji sejmów nadzwyczajnych, po pewnych przekształceniach nadal były one zwoływane, a klasyfikacja sejmów generalnie się nie zmieniła. Natomiast za panowania Jana Kazimierza sejmy stały się mozaiką różnych form. W efekcie pojawiają się znaczące rozbieżności $\mathrm{w}$ ich kwalifikacji przez badaczy epoki, o wiele większe niż w przypadku okresu poprzedniego. Ilustracją niech będzie poniższa tabela, przedstawiająca opis sejmu w świetle konstytucji tego sejmu (VL), W. Konopczyńskiego w Chronologii sejmów polskich (W. K.), koncepcji S. Ochmann-Staniszewskiej i Z. Staniszewskiego zamieszczonej w II tomie obszernej publikacji o sejmach tego okresu (S. O.-S., Z. S.) oraz poglądów autorki niniejszego opracowania (I. L.-M.)

Tabela 1. Rodzaje sejmów - porównanie koncepcji

\begin{tabular}{|c|c|c|c|c|}
\hline Sejm & VL & W. K. & S. O.-S., Z. S. & I. L.-M. \\
\hline $\mathbf{1}$ & $\mathbf{2}$ & $\mathbf{3}$ & $\mathbf{4}$ & $\mathbf{5}$ \\
\hline 1649 & trzyniedzielny & koronacyjny & $\begin{array}{c}\text { nadzwyczajny } \\
\text { trzytygodniowy }\end{array}$ & $\begin{array}{c}\text { nadzwyczajny } \\
\text { krótki (uchwała } \\
\text { sejmu elekcyjnego) }\end{array}$ \\
\hline $1649-1650$ & sześćniedzielny & zwyczajny & $\begin{array}{c}\text { zwyczajny } \\
\text { sześciotygodniowy }\end{array}$ & $\begin{array}{c}\text { zwyczajny } \\
\text { obligatoryjny }\end{array}$ \\
\hline 1650 & dwuniedzielny & $\begin{array}{c}\text { jest: zwyczajny } \\
\text { powinno być: } \\
\text { nadzwyczajny }\end{array}$ & $\begin{array}{c}\text { nadzwyczajny } \\
\text { krótki } \\
\text { nadzwytyodniowy } \\
\text { (uchwała sejmu } \\
\text { poprzedniego) }\end{array}$ \\
\hline
\end{tabular}

${ }^{50}$ Pkt 11, Seym dwuniedzielny, VL, t. IV, s. $130 .{ }^{51}$ Pkt 11, Seym dwuniedzielny, VL, t. IV, s. 130. 
cd. Tab. 1

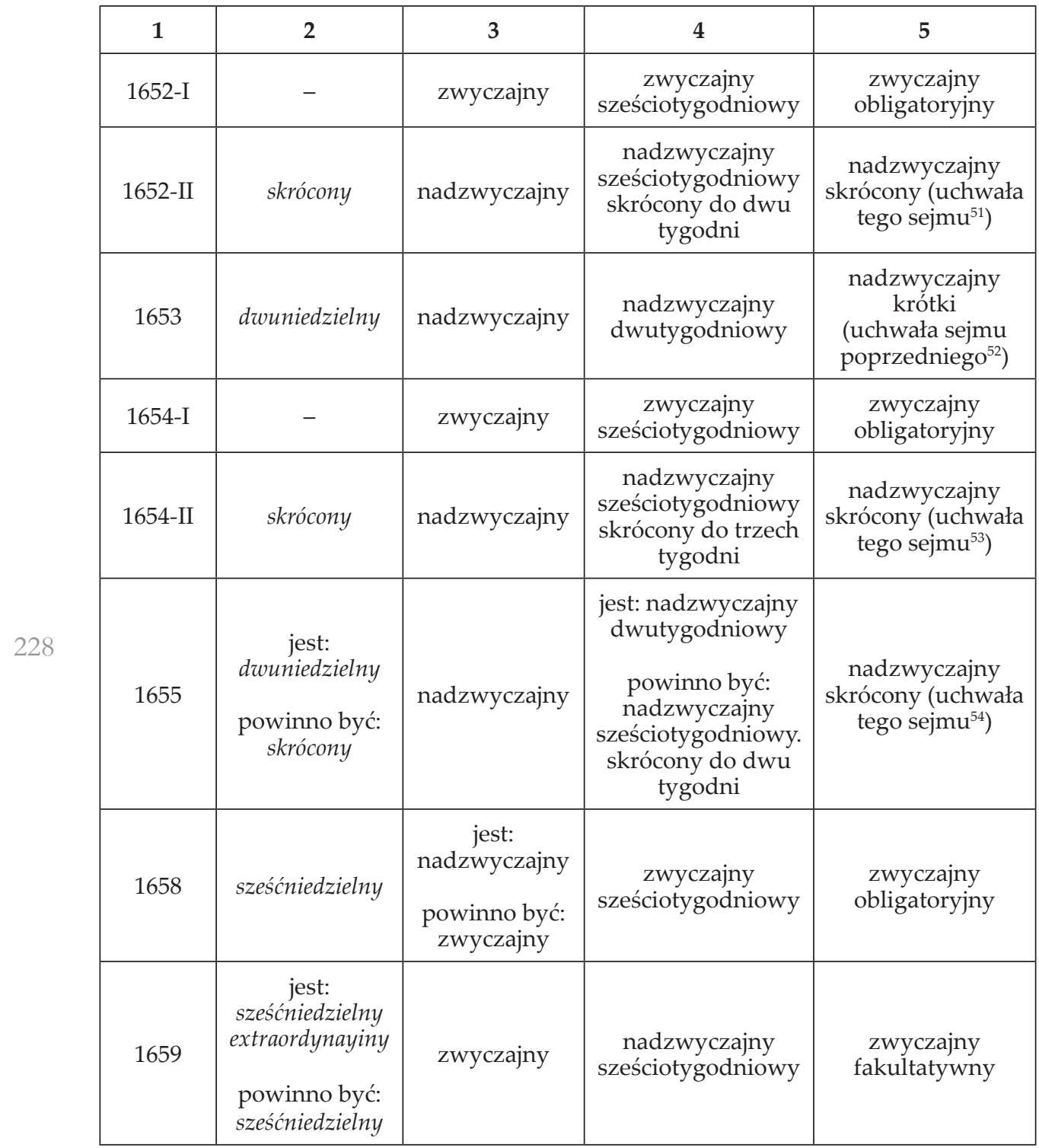

${ }^{51}$ Pkt 2, Skrócenie Seymu, VL, t. IV, s. 165.

${ }^{52}$ Pkt 17, Seym dwuniedzielny, VL, t. IV, s. 169.

${ }^{53}$ VL, t. IV, s. 204.

${ }^{54}$ Pkt 12, Skrócenie Seymu, VL, t. IV, s. 221. 


\begin{tabular}{|c|c|c|c|c|}
\hline 1661 & sześćniedzielny & zwyczajny & $\begin{array}{c}\text { zwyczajny } \\
\text { sześciotygodniowy }\end{array}$ & $\begin{array}{l}\text { zwyczajny } \\
\text { obligatoryjny }\end{array}$ \\
\hline 1662 & $\begin{array}{c}\text { jest: } \\
\text { ekstraordynaryiny } \\
\text { powinno być: } \\
\text { sześćniedzielny }\end{array}$ & zwyczajny & $\begin{array}{l}\text { jest: nadzwyczajny } \\
\text { dwutygodniowy } \\
\text { powinno być: } \\
\text { nadzwyczajny } \\
\text { dwutygodniowy } \\
\text { przedłużony do } \\
\text { sześciu tygodni }\end{array}$ & $\begin{array}{l}\text { zwyczajny } \\
\text { fakultatywny }\end{array}$ \\
\hline 1664-1665 & - & zwyczajny & $\begin{array}{c}\text { zwyczajny } \\
\text { sześciotygodniowy }\end{array}$ & $\begin{array}{l}\text { zwyczajny } \\
\text { obligatoryjny }\end{array}$ \\
\hline 1665 & - & nadzwyczajny & $\begin{array}{l}\text { nadzwyczajny } \\
\text { dwutygodniowy }\end{array}$ & $\begin{array}{c}\text { nadzwyczajny } \\
\text { (uwaga! uchwała } \\
\text { rady senatu) }\end{array}$ \\
\hline 1666-I & - & zwyczajny & $\begin{array}{c}\text { zwyczajny } \\
\text { sześciotygodniowy }\end{array}$ & $\begin{array}{l}\text { zwyczajny } \\
\text { fakultatywny }\end{array}$ \\
\hline 1666-II & - & zwyczajny & $\begin{array}{c}\text { zwyczajny } \\
\text { sześciotygodniowy }\end{array}$ & $\begin{array}{c}\text { zwyczajny } \\
\text { obligatoryjny }\end{array}$ \\
\hline 1667 & sześćniedzielny & zwyczajny & $\begin{array}{l}\text { nadzwyczajny } \\
\text { dwutygodniowy } \\
\text { przedłużony do } \\
\text { sześciu tygodni }\end{array}$ & $\begin{array}{l}\text { zwyczajny } \\
\text { fakultatywny }\end{array}$ \\
\hline 1668-I & - & $\begin{array}{l}\text { jest: } \\
\text { nadzwyczajny } \\
\text { powinno być: } \\
\text { zwyczajny }\end{array}$ & $\begin{array}{c}\text { zwyczajny } \\
\text { sześciotygodniowy }\end{array}$ & $\begin{array}{l}\text { zwyczajny } \\
\text { obligatoryjny }\end{array}$ \\
\hline 1668-II & skrócony & $\begin{array}{l}\text { nadzwyczajny } \\
\text { (abdykacyjny) }\end{array}$ & $\begin{array}{c}\text { nadzwyczajny } \\
\text { sześciotygodniowy } \\
\text { skrócony do trzech } \\
\text { tygodni }\end{array}$ & $\begin{array}{l}\text { nadzwyczajny } \\
\text { skrócony (uchwała } \\
\text { tego sejmu }{ }^{55} \text { ) }\end{array}$ \\
\hline
\end{tabular}

Źródło: opracowanie własne.

${ }^{55}$ VL, t. IV, s. 478. 


\section{Bibliografia}

\section{Źródła drukowane}

Skrzetuski W., Prawo pospolite narodu polskiego, t. I, Warszawa 1782, s. 250.

Volumina Constitutionum, t. II, 1550-1609, v. 1-2, 1550-1585, do druku przygotowali S. Grodziski, I. Dwornicka i W. Uruszczak, Warszawa 2005.

Volumina Legum, t. II, III, IV, wyd. J. Ohryzko, Petersburg 1859.

\section{Opracowania}

Dorobisz J., Sejm nadzwyczajny z 1624 roku, Opole 1994.

Dorobisz J., Z problematyki procedury sejmów nadzwyczajnych za Zygmunta III, [w:] Studia z Dziejów Rzeczypospolitej Szlacheckiej, AUWr, 945. Historia, t. LXVI, Wrocław 1988.

Kołodziej R., Pierwszy sejm z 1637 roku, Torun 2004.

Konopczyński W., Chronologia sejmów polskich 1493-1793, Kraków 1948.

Kutrzeba S., Historia ustroju Polski w zarysie, Lwów 1908.

Lengnich G., Prawo pospolite Królestwa Polskiego, Kraków 1836.

Lewandowska-Malec I., Sejm walny koronny Rzeczypospolitej Obojga Narodów i jego dorobek ustawodawczy (1587-1632), Kraków 2009.

Lewandowska-Malec I., Sejmy nadzwyczajne w dziejach polskiego parlamentaryzmu, „Studia z Dziejów Państwa i Prawa Polskiego” [Kraków] 2007, t. X.

Ochmann-Staniszewska S., Staniszewski Z., Sejm Rzeczypospolitej za panowania Jana Kazimierza Wazy. Prawo - doktryna - praktyka, t. II, AUWr, 2258, Historia, t. CXLVII, Wrocław 2000.

Opaliński E., Sejm srebrnego wieku 1587-1652, Warszawa 2001.

Paradowski P., Wobliczu "nagłych potrzeb" Rzeczypospolitej. Sejmy ekstraordynaryjne za panowania Władysława IV Wazy, Torun 2005.

Płaza S., Wielkie bezkrólewia, Kraków 1988.

Płaza S., Sucheni-Grabowska A., Z badań nad parlamentaryzmem XVI wieku, CPH, 1974, t. XXVI, z. 1. 